\section{London Television Service}

THE first public demonstrations of the reception of television programmes from the British Broadcasting Corporation's experimental station at Alexandra Palace were given on the occasion of the Radio Exhibition at Olympia in August 1936. These were followed in November by the inauguration of the present television broadcasting service from the same station. In accordance with the recommendations of H.M. Postmaster-General's Television Advisory Committee, the programmes were shared between two separate transmitters installed respectively by the Baird Television Co., Ltd., and by the Marconi-E.M.I. Television Co., Ltd. The object of this arrangement was to enable an adequate, practical test to be made to ascertain the relative merits of the two systems of transmission, which differ considerably in technical details and in scanning speed and picture frequency. According to an announcement in The Times, the Television Advisory Committee has now recommended that the experimental period should be terminated, and that a single set of technical standards should be adopted for public transmissions from the London station. This recommendation has been approved by the Postmaster-General, and provides for a standard of interlaced scanning at a speed of 405 lines per picture, with a picture frequency of 50 per second. The result of this decision is that in future the B.B.C. television programmes from the Alexandra Palace will be emitted by the Marconi-E.M.I. system, although it may be possible to convert the Baird system to the required standards at a later date. The adoption of the new standards, which will not be altered before the end of 1938 , will render possible a certain degree of simplification in the design of television receivers. In common with those of other firms, the existing receiving sets made by the Baird Company are capable of receiving the Marconi-E.M.I. transmissions.

\section{Sir Joseph Banks's London House}

IT is too late to protest against the destruction of Sir Joseph Banks's town house at 32 Soho Square, and our commercial age will demand its removal together with many other examples of eighteenth century domestic architecture. Only the tablet placed on the house in 1911 and the description and plan in Country Life of September 27, 1913, will remain to us. Sir Joseph moved there from New Burlington Street in the autumn of 1777 , and remained there until his death in 1820. The Linnean Society leased part of the house from 1827 until 1857, when it moved to Old Burlington House. The subsequent tenants, including the Hospital for Diseases of the Heart and a firm of decorators, made many alterations, but the fine ceilings and an exquisite overmantel and fireplace were reminders of its original beauty. Banks's magnificent collections were housed there under the able care of the botanist. librarians Solander, Dryander and Robert Brown. Banks bequeathed his collections to Brown, who transferred them to the British Museum, remaining in charge of them until his death in 1858.

\section{A National Industrial Health Service}

The Medical Research Council, with the Industrial Health Research Board as well as the various colleges and schools of the universities, are occupied with research work which has, either directly or poten. tially, an industrial application; the time-lag, however, in applying or testing the results of such research work is usually too long. Some large organizations provide a full-time medical service, but there are many which have not yet realized that there is any need for such a service, and the smaller organizations cannot afford this. Even when a medical officer is appointed, his previous education has not trained him to recognize, or to deal adequately with a number of problems he meets, nor does he know where to get the required knowledge which, unknown to him, may exist. With the rapid development of new processes utilizing new products, it is necessary that their physiological and toxicological properties should be studied : also the medical officer will find himself confronted by a number of psychological problems concerning which he knows little or nothing. Discussions of the problem of making practically effective in industry the results of research work of medical importance have appeared in Industrial Welfare of December 15 and the British Medical Journal of December 5. Since it seems impracticable to add anything to the curriculum of the medical student, a post-graduate course is suggested. The works' doctor must be able to ascertain that $(a)$ the workers taken on for certain jobs are reasonably fit to carry them out from the health point of view, and $(b)$, in co-operation with works' engineers and others, that the conditions under which the employees are required to work are not prejudicial to their health.

SrNCE small organizations cannot afford to give the medical services possible to the larger ones, some way of providing them must be considered. One way would be for a number of small organizations to be served by one medical officer ; there are, of course, difficulties in the way, but they need not be insuperable. Who shall pay for these services must also be considered. Shall the organizations or the State? It is suggested that a National Industrial Health Service should be formed, which should include not only a medically qualified personnel, but also a number of engineers who have been trained in the study of works' practice from the physiological point of view, physiologists and medical-industrial psychologists. Not only would the curative aspect of industrial medical practice be dealt with but also the preventive, and this would involve the study of the conditions of work and the total environment of the employees. It would also be the business of this service to keep in touch with existent research work and bring it to the notice of those concerned. There should also be some arrangement whereby the application of a particular piece of research or investigation could be considered : for this a special committee or board is needed, comprising representatives of the State, the industry concermed, the trade union or unions repre. senting the particular industry, and the research worker or organization responsible. 